\title{
A Prospective Comparative Study between the Efficacy of Uterine Compression Sutures (B-Lynch) and Bilateral Uterine Artery Ligation for the Prevention of Atonic Postpartum Haemorrhage during Caesarean Section in High Risk Women
}

\author{
AHMED T. ABDEL-FATAH, M.D.*; MOHAMED E. HAMMOUR, M.D.*; \\ ABD EL-MONIEM M. ZAKARIA, M.D.*; IBRAHEIM ABO EL-MAGED, M.D.*; \\ WAEL TAHA, M.D.* and MOHAMED A. AHMED, M.Sc.** \\ The Department of Obstetrics and Gynecology, Faculty of Medicine, Al-Azhar University* and El-Sahel Teaching Hospital**
}

\begin{abstract}
Background: In the current study was held to compare the efficacy of uterine compression sutures and bilateral uterine artery ligation for the prevention of atonic postpartum haemorrhage during Caesarean section in high risk women.

Aim of the Study: This study Compartive study between the efficacy of uterine compression suture (B-Lynch) and bilateral uterine artery ligation for the prevention of atonic post-partum hemorrhage during caesarean section in high risk women.
\end{abstract}

Patients and Methods: This study was held on one hundred and fifty patients divided in to 3 groups.

- Group A: 50 patients would had prophylactic B lynch sutures and prophylactic medical treatment.

- Group B: 50 patients would had prophylactic bilateral uterine artery ligation and prophylactic medical treatment.

- Group C: 50 patients (control group) would had only prophylactic medical treatment.

Results: No statically differences between study groups and between study groups and control group as regarding demographic characteristics of the patients.

No statically differences between study groups and between study groups and control group as regarding risk factors for atony.

No statically difference between study groups as regarding 1 st 6 hour postpartum vaginal bleeding but there was significantly difference between both study groups and control groups $p<0.001$.

NO statically difference between study groups as regarding total blood loss but there was significantly difference between both study groups and control group $<0.001$.

Correspondence to: Dr. Ahmed T. Abdel-Fatah The Department of Obstetrics and Gynecology, Faculty of Medicine, Al-Azhar University
No statically difference between study groups and control as regarding pre-operative hemoglobin and hematocrit level.

No statically difference between study groups as regarding post-operative hemoglobin and hematocrit level, but there was statically difference between study groups and control group as regarding post-operative hemoglobin and hematocrit values $p<0.001$.

No statically difference between study groups as regarding 6 hour postoperative pulse, but there was significantly difference between study groups and control group $p<0.001$.

No statically difference between study groups as regarding postoperative complication, but there was significant difference between study groups and control group $p<0.001$.

Setting: This study was held on one hundred and fifty patients from El Sahel teaching hospital at department of obstetrics and gynecology Study design: A Prospective Comparative study.

Conclusion: There is no difference between uterine compression suture (B-Lynch) suture and bilateral uterine artery ligation in prevention of postpartum hemorrhage; while both maneuver are effective as a prophylaxis against postpartum hemorrhage as shown by the results of this study. There can significantly reduce blood loss after cesarean section.

Our data demonstrated, that uterine compression suture (B-Lynch) and bilateral uterine artery ligation can be used safely to reduce bleeding after CS as there use was not associated with any significant maternal and neonatal side effects.

Key Words: Postpartum hemorrhage (PPH) - Bilateral Uterine Artery Ligation (BUAL) - B-lynch suture.

\section{Introduction}

POSTPARTUM haemorrhage continues to be leading cause of maternal mortality and morbidity, accounting for more than 125000 deaths per year 
across the world. Prompt diagnosis and effective action are the cornerstones of management and are crucial to prevent maternal haemorrge [1].

Primary PPH occurs within 24 hours of delivery. It is defined as a reduction in the patient's haematocrit level of more than $10 \%$ of the prenatal value or blood loss causing haemodynamic instability of sufficient seriousness to require blood transfusion [2]. PPH complicates approximately $3.7 \%$ of vaginal and $6.4 \%$ of caesarean deliveries [3].

Uterine atony accounts for $75 \%-90 \%$ of primary $\mathrm{PPH}$. As the old proverb goes", Prevention is better than cure", every obstetrician should be proficient with identification of risk factors for PPH and prevent it. The onus is on the practising obstetrician in rural areas where the blood bank facilities are not readily available. Identification of risk factors of PPH is of paramount importance [4].

Most cases of PPH are due to uterine atony. The causes of uterine atony are general anaesthesia, poorly perfused myometrium in shock, over distended uterus with multiple fetuses, excessive amniotic fluid, following rapid or prolonged labour, oxytocin induced or augmented labour, grand or high multiparity, history of prior uterine atony, chorioamnionitis, uterine fibroids, placents praevia, following tocolytic therapy, following magnesium sulphate therapy [5].

Postpartum haemorrhage can also occur as the result of retained placental tissue in an avulsed cotyledon, a succenturiate or accessory lobe, an abnormally adherent placenta accrete, increta or percreta or a placental abruption [5]

Other causes of postpartum haemorrhage include uterine rupture, genital tract lacerations, uterine inversion or coagulopathies [5] .

The traditional management of PPH begins with conservative methods such as bimanual compression, medical therapy with uterotonic agents, uterine tamponade with balloons and occasionally arterial embolization. The failure of which often mandates surgical intervention [6].

Surgical measures such as ligation of major pelvic vessels demand a rarely used skill possessed by few registrars. In the event of intractable haemorrhage despite the above measures hysterectomy is usually the final resort [7].

However hysterectomy after primary PPH has appreciable drawbacks-not only does it result in infertility, there are technical difficulties in removing lower uterine segment and these increase the likelihood of injury to the bladder or ureter [8] .

Surgical techniques offering conservative management of primary PPH have four stitches in atonic postpartum haemorrhage.

Some procedures involve compression by bracelike suturing to preserve the uterus after atonic bleeding, also in combination with intrauterine ballon catheter. Other workers have described multiple square sutures and vertical penetrating sutures within the lower uterine segment combined with oblique penetrating corpus sutures or multiple vertical sutures [6,9].

However, theoretical concerns have been raised on the potential risk of occlusion of the uterine cavity and blood entrapment, as the uterus is transfixed to back to place the suture [10]

During pregnancy $90 \%$ of the blood supply to the uterus comes from the uterine arteries and the rest from the ovarian and vaginal arteries. Occlusion of the uterine arteries reduce most of the uterine blood flow and produce uterine ischemia [11].

In uncontrollable haemorrhage the uterine arteries lose their ability to constrict because of an unidentified mechanism and their ligation seems to be justifiable treatment [11]

\section{Patients and Methods}

Study design: A prospective comparative controlled study.

This study will be conducted at El-Sahel Teaching Hospital at the Department of Obstetrics and Gynaecology from June 2016 - Dec. 2017. A total of 150 patients with high risk for atonic postpartum haemorrhage will be recruited.

They will be selected according to Inclusion and Exclusion criteria:

Inclusion criteria: Patients undergoing caesarean section with high risk for atonic postpartum haemorrhage:

- Polyhydramnios.

- Multiple gestations.

- Macrosomia.

- Prolonged labor.

- Chorionamnionitis.

- Tocolytic agents.

- Halogenated anesthetic agents.

- High parity. 
- Abruptio placentae.

- Courvelliar's uterus.

- Anemia.

Exclusion criteria: patients with:

- Thrombocytopenic purpura.

- Hypertensive disease.

- Uterine myoma.

- Anticoagulation therapy.

- Coagulation factor deficiency.

- Systemic disease of hemorrhagic nature.

- Consumptive coagulopathy.

- Müllerian malfunction.

The patienst will be distributed in three groups:

- Group A: 50 patients will have prophylactic B lynch sutures and prophylactic medical treatment.

- Goup B: 50 patients will have prophylactic bilateral uterine artery ligation and prophylactic medical treatment.
- Group C: 50 patients (control group) will have only prophylactic medical treatment.

The patients would be assessed by:

- Vital data, pulse and B.P.

- Contraction of the uterus.

- Vaginal bleeding.

- Preoperative and postoperative complete blood picture for hemoglobin and hematocrit levels.

- Future intervention surgery.

\section{Results}

This table shows no significant difference between groups regarding demographic characteristics.

This table shows no significant difference between groups regarding risks for atony.

Table (3) and Fig. (1) show that: 1 st 6 hours Postoperative vaginal bleeding was significantly lower among group A, B than among control group.

Table (1): Demographic characteristics among both groups.

\begin{tabular}{|c|c|c|c|c|c|}
\hline & $\begin{array}{l}\text { Group A } \\
(\mathrm{N}=50)\end{array}$ & $\begin{array}{c}\text { Group B } \\
(\mathrm{N}=50)\end{array}$ & $\begin{array}{l}\text { Group C } \\
(\mathrm{N}=50)\end{array}$ & $\mathrm{F} / \mathrm{X}^{2} \#$ & $p$-value \\
\hline $\begin{array}{l}\text { Age (years): } \\
\text { Mean } \pm \mathrm{SD} \\
\text { Range }\end{array}$ & $\begin{array}{l}30.33 \pm 3.24 \\
21-39\end{array}$ & $\begin{array}{l}30.63 \pm 3.27 \\
21-39\end{array}$ & $\begin{array}{l}30.23 \pm 2.63 \\
23-38\end{array}$ & 1.277 & 0.575 \\
\hline $\begin{array}{l}B M I\left(k g / m^{2}\right): \\
\quad \text { Mean } \pm \text { SD } \\
\text { Range }\end{array}$ & $\begin{array}{l}29.22 \pm 2.43 \\
22.65-36.09\end{array}$ & $\begin{array}{l}29.51 \pm 2.45 \\
22.87-36.45\end{array}$ & $\begin{array}{l}29.42 \pm 2.53 \\
23.05-35.18\end{array}$ & 0.587 & 0.264 \\
\hline $\begin{array}{l}\text { Parity }(N, \%): \\
\text { Primigravida } \\
\text { Multipara }\end{array}$ & $\begin{array}{l}15(30.0 \%) \\
35(70.0 \%)\end{array}$ & $\begin{array}{l}16(32.0 \%) \\
34(68.0 \%)\end{array}$ & $\begin{array}{l}18(36.0 \%) \\
32(64.0 \%)\end{array}$ & 3.994\# & 0.262 \\
\hline $\begin{array}{c}\text { Number of CS: } \\
\text { P1CS } \\
\text { P2CS } \\
\text { P3CS } \\
\text { P4CS }\end{array}$ & $\begin{array}{l}9(18.0 \%) \\
7(14.0 \%) \\
10(20.0 \%) \\
9(18.0 \%)\end{array}$ & $\begin{array}{l}9(18.0 \%) \\
6(12.0 \%) \\
9(18.0 \%) \\
10(20.0 \%)\end{array}$ & $\begin{array}{l}8(16.0 \%) \\
7(14.0 \%) \\
8(16.0 \%) \\
9(18.0 \%)\end{array}$ & $0.235 \#$ & 0.106 \\
\hline $\begin{array}{l}\text { GA (weeks): } \\
\text { Mean士 SD } \\
\text { Range }\end{array}$ & $\begin{array}{l}39.43 \pm 0.61 \\
38-41\end{array}$ & $\begin{array}{l}39.82 \pm 0.61 \\
38-41\end{array}$ & $\begin{array}{l}39.43 \pm 0.61 \\
38-41\end{array}$ & 1.595 & 0.718 \\
\hline & $\begin{array}{c}\text { Group A } \\
(\mathrm{N}=50)\end{array}$ & $\begin{array}{c}\text { Group B } \\
(\mathrm{N}=50)\end{array}$ & $\begin{array}{c}\text { Group C } \\
(\mathrm{N}=50)\end{array}$ & $X^{2}$ & $p$-value \\
\hline Multiparity & $23(46.0 \%)$ & $22(44.0 \%)$ & $22(44.0 \%)$ & 2.597 & 0.415 \\
\hline Anemia & $12(24.0 \%)$ & $13(26.0 \%)$ & $13(26.0 \%)$ & 3.380 & 0.541 \\
\hline Emergency section & $11(22.0 \%)$ & $10(20.0 \%)$ & $11(22.0 \%)$ & 3.713 & 0.594 \\
\hline Polyhydramnios & $3(6.0 \%)$ & $3(6.0 \%)$ & $3(6.0 \%)$ & 3.816 & 0.611 \\
\hline Chrioamniotis & $3(6.0 \%)$ & $3(6.0 \%)$ & $3(6.0 \%)$ & 3.767 & 0.603 \\
\hline Prolonged delivery & $3(6.0 \%)$ & $2(4.0 \%)$ & $4(8.0 \%)$ & 3.857 & 0.617 \\
\hline Multiple pregnancy & $2(4.0 \%)$ & $2(4.0 \%)$ & $2(4.0 \%)$ & 2.916 & 0.467 \\
\hline Macrosomic baby & $2(4.0 \%)$ & $2(4.0 \%)$ & $2(4.0 \%)$ & 2.169 & 0.347 \\
\hline
\end{tabular}


Table (3): 1 st 6 hours Postoperative vaginal bleeding $(\mathrm{mL})$ among both groups.

\begin{tabular}{llllll}
\hline & $\begin{array}{c}\text { Group A } \\
(\mathrm{N}=50)\end{array}$ & \multicolumn{1}{c}{$\begin{array}{c}\text { Group B } \\
(\mathrm{N}=50)\end{array}$} & $\begin{array}{c}\text { Group C } \\
(\mathrm{N}=50)\end{array}$ & ANOVA & $p$-value \\
\hline Mean \pm SD & $251.02 \pm 21.83$ & $246.00 \pm 21.39$ & $332.62 \pm 18.87$ & & \\
Range & $201-341$ & $197-334$ & $282-376$ & 7.491 & $<0.001$ a,b \\
95\% C.I. & $248.17-253.88$ & $243.20-248.80$ & $330.17-335.07$ & & \\
\hline CI: Confidence interval & Difference between group A and group B ( $p$-value 0.321 NS) \\
a : Significant difference between Group A and Group C. & \\
b : Significant difference between Group B and Group C.
\end{tabular}

Table (4) and Fig. (2) show that: Total blood loss was significantly lower among group A, B than among control group.

Table (5) and Fig. (3) show that: No significant difference between groups regarding basal Hemoglobin. 24 hours postoperative Hemoglobin was significantly higher among group A, B than among control group.

Table (6) and Fig. (5) show that: Immediate and 6 hours Postoperative pulse was significantly lower among group A, B than among control group.

Table (7) and Fig. (6) show that: No significant difference between the studied groups regarding operation duration.

Table (7) and Fig. (8) show that: Incidence of PPH \& Blood transfusion was significantly less frequent among group A,B than among control group.

In the group A, B 2 patients had PPH with blood loss $>1000 \mathrm{cc}$ and in the control group 6 patients had PPH with blood loss $>1000 \mathrm{cc}$. Thus the uterine compression suture and bilateral uterine artery ligation reduced incidence of $\mathrm{PPH}$ in the group A,B. In the study group A 2 patients needed further surgical intervention to stop PPH, where 1 patient needed bilateral uterine artery ligation and other patient need bilateral internal iliac artery ligation in group B $1 \mathrm{p} 1$ tient need further surgical intervention we done B-Lynch suture.

In the control group 4 patients required further surgery to stop bleeding. 2 patients needed bilateral uterine artery ligation, 1 patient underwent bilateral internal iliac artery ligation. 1 patients underwent B-Lynch suture.

Table (4): Total blood loss (mL) among the both groups.

\begin{tabular}{|c|c|c|c|c|c|}
\hline & $\begin{array}{c}\text { Group A } \\
(\mathrm{N}=50)\end{array}$ & $\begin{array}{c}\text { Group B } \\
(\mathrm{N}=50)\end{array}$ & $\begin{array}{c}\text { Group C } \\
(\mathrm{N}=50)\end{array}$ & ANOVA & $p$-value \\
\hline $\begin{array}{l}\text { Mean } \pm \text { SD } \\
\text { Range } \\
95 \% \text { C.I. }\end{array}$ & $\begin{array}{l}785.91 \pm 52.33 \\
562-1134 \\
779.18-792.64\end{array}$ & $\begin{array}{l}770.19 \pm 51.28 \\
551-1112 \\
763.59-776.79\end{array}$ & $\begin{array}{l}964.61 \pm 40.60 \\
557-1384 \\
959.31-969.82\end{array}$ & 6.367 & $<0.001$ a,b \\
\hline \multicolumn{6}{|c|}{$\begin{array}{l}\text { CI: Confidence interval. Difference between group A and group B ( } p \text {-value } 0.117 \text { NS). } \\
\text { a : Significant difference between Group A and Group C. } \\
\text { b : Significant difference between Group B and Group C. }\end{array}$} \\
\hline Time & $\begin{array}{c}\text { Group A } \\
(\mathrm{N}=50)\end{array}$ & $\begin{array}{c}\text { Group B } \\
(\mathrm{N}=50)\end{array}$ & $\begin{array}{c}\text { Group C } \\
(\mathrm{N}=50)\end{array}$ & ANOVA & $p$-value \\
\hline \multicolumn{6}{|l|}{ Before: } \\
\hline $\begin{array}{l}\text { Mean } \pm \text { SD } \\
\text { Range } \\
95 \% \text { C.I. }\end{array}$ & $\begin{array}{l}10.51 \pm 0.91 \\
7.89-13.24 \\
10.41-10.62\end{array}$ & $\begin{array}{l}10.62 \pm 0.92 \\
7.96-13.38 \\
10.52-10.72\end{array}$ & $\begin{array}{l}10.62 \pm 1.01 \\
7.58-12.94 \\
10.51-10.72\end{array}$ & 0.486 & 0.276 \\
\hline $\begin{array}{c}24 \text { hours afte } \\
\text { Mean } \pm \text { SD } \\
\text { Range } \\
\text { 95\% C.I. }\end{array}$ & $\begin{array}{l}8.69 \pm 0.91 \\
5.96-11.22 \\
8.59-8.80\end{array}$ & $\begin{array}{l}8.78 \pm 0.92 \\
6.02-11.33 \\
8.68-8.88\end{array}$ & $\begin{array}{l}7.99 \pm 1.01 \\
5.06-10.51 \\
7.89-8.09\end{array}$ & 2.792 & $<0.001 \mathbf{a , b}$ \\
\hline $\begin{array}{l}\text { Change: } \\
\text { Mean } \pm \mathrm{SD} \\
\text { Range } \\
95 \% \text { C.I. } \\
p \text {-value }\end{array}$ & $\begin{array}{l}1.82 \pm 0.10 \\
1.52-2.12 \\
1.82-1.82 \\
<0.001\end{array}$ & $\begin{array}{l}1.84 \pm 0.10 \\
1.53-2.14 \\
1.84-1.84 \\
<0.001\end{array}$ & $\begin{array}{l}2.63 \pm 0.10 \\
2.33-2.93 \\
2.63-2.63 \\
<0.001\end{array}$ & 3.630 & $<0.001 \mathbf{a , b}$ \\
\hline
\end{tabular}

CI: Confidence interval.

Difference between group A and group B according $\mathrm{Hb}$ after $24 \mathrm{hr}$ ( $p$-value $0.482 \mathrm{NS}$ )

Difference between group A and group B according Hb change ( $p$-value $0.357 \mathrm{NS}$ ).

a : Significant difference between Group A and Group C.

b : Significant difference between Group B and Group C. 
Table (6): Immediate and 6 hours Postoperative pulse (beat/ minute) among the studied groups.

\begin{tabular}{|c|c|c|c|c|c|}
\hline Time & $\begin{array}{c}\text { Group A } \\
(\mathrm{N}=50)\end{array}$ & $\begin{array}{c}\text { Group B } \\
(\mathrm{N}=50)\end{array}$ & $\begin{array}{c}\text { Group C } \\
(\mathrm{N}=50)\end{array}$ & ANOVA & $p$-value \\
\hline \multicolumn{6}{|l|}{ Immediate: } \\
\hline Mean \pm SD & $100.59 \pm 5.76$ & $101.60 \pm 5.82$ & $111.11 \pm 6.27$ & 5.296 & $<0.001 \mathbf{a}^{\mathbf{a}} \mathbf{b}$ \\
\hline Range & $85.94-117.28$ & $86.79-118.45$ & $90.99-128.40$ & & \\
\hline 95\% C.I. & $99.89-101.30$ & $100.89-102.32$ & $110.30-111.92$ & & \\
\hline \multicolumn{6}{|l|}{ Hour-6: } \\
\hline Mean \pm SD & $88.56 \pm 5.76$ & $89.45 \pm 5.82$ & $98.88 \pm 5.96$ & 4.974 & $<0.001^{\mathbf{a}^{\prime} \mathbf{b}}$ \\
\hline Range & $73.80-106.16$ & $74.54-107.22$ & $81.89-115.25$ & & \\
\hline 95\% C.I. & $87.75-89.27$ & $88.63-90.16$ & $98.07-99.58$ & & \\
\hline$p$-value & $<0.001$ & $<0.001$ & $<0.001$ & & \\
\hline
\end{tabular}

CI: Confidence interval.

Difference between group A and group B according pulse immediate ( $p$-value $0.492 \mathrm{NS}$ ).

Difference between group A and group B according pulse after 6hr ( $p$-value 0.519 NS)

a : Significant difference between Group A and Group C.

b : Significant difference between Group B and Group C.

Table (7): Operation duration (minutes) among the studied groups.

\begin{tabular}{lllllr}
\hline Time & $\begin{array}{c}\text { Group A } \\
(\mathrm{N}=50)\end{array}$ & $\begin{array}{c}\text { Group B } \\
(\mathrm{N}=50)\end{array}$ & $\begin{array}{c}\text { Group C } \\
(\mathrm{N}=50)\end{array}$ & ANOVA & $p$-value \\
\hline Mean $\pm \mathrm{SD}$ & $52.67 \pm 6.17$ & $53.20 \pm 6.23$ & $52.77 \pm 6.87$ & 0.427 & 0.670 \\
Range & $36-71$ & $37-71$ & $34-71$ & & \\
$95 \%$ C.I. & $51.86-53.48$ & $52.38-54.02$ & $51.86-53.68$ & & \\
\hline
\end{tabular}

CI: Confidence interval.

Table (8): Postoperative complications among the studied groups.

\begin{tabular}{lcccccc}
\hline Measures & $\begin{array}{c}\text { Group A } \\
(\mathrm{N}=50)\end{array}$ & $\begin{array}{c}\text { Group B } \\
(\mathrm{N}=50)\end{array}$ & $\begin{array}{c}\text { Group C } \\
(\mathrm{N}=50)\end{array}$ & $\mathrm{X} 2$ & $p$-value & $\begin{array}{c}\mathrm{RR} \\
(95 \% \mathrm{CI})\end{array}$ \\
\hline PPH & $2(4.0 \%)$ & $2(4.0 \%)$ & $6(12 \%)$ & 7.281 & $0.028^{\mathbf{a}} \mathbf{b}$ & $0.41(0.17-0.84)$ \\
Blood transfusion & $2(4.0 \%)$ & $2(4.0 \%)$ & $7(14 \%)$ & 9.150 & $0.016^{\mathbf{a}} \mathbf{b}$ & $0.37(0.19-0.90)$ \\
Further surgery & $2(4.0 \%)$ & $1(2.0 \%)$ & $4(8 \%)$ & 0.177 & 0.673 & $0.73(0.35-1.50)$ \\
$\quad$ - Bilateral UAL & $1(2.0 \%)$ & $0(0.0 \%)$ & $2(4 \%)$ & & & \\
$\quad$ - Bilateral II artery ligation & $1(2.0 \%)$ & $0(0.0 \%)$ & $1(2 \%)$ & & & \\
$\quad$ - B-lynch sutures & $0(0.0 \%)$ & $1(2.0 \%)$ & $1(2 \%)$ & & & \\
Bladder injury & $1(2.0 \%)$ & $1(2.0 \%)$ & $2(4 \%)$ & 0.073 & 0.785 & $0.74(0.14-3.63)$ \\
\hline
\end{tabular}

RR: Relative risk.

CI: Confidence interval.

Difference between group A and group B according PPH ( $p$-value $0.253 \mathrm{NS}$ ).

Difference between group A and group B according blood transfusion ( $p$-value $0.174 \mathrm{NS}$ )

Difference between group A and group B according further surgery ( $p$-value $0.264 \mathrm{NS}$ ).

Difference between group A and group B according bladder injury ( $p$-value $0.296 \mathrm{NS}$ ).

a : Significant difference between Group A and Group C.

b : Significant difference between Group B and Group C.

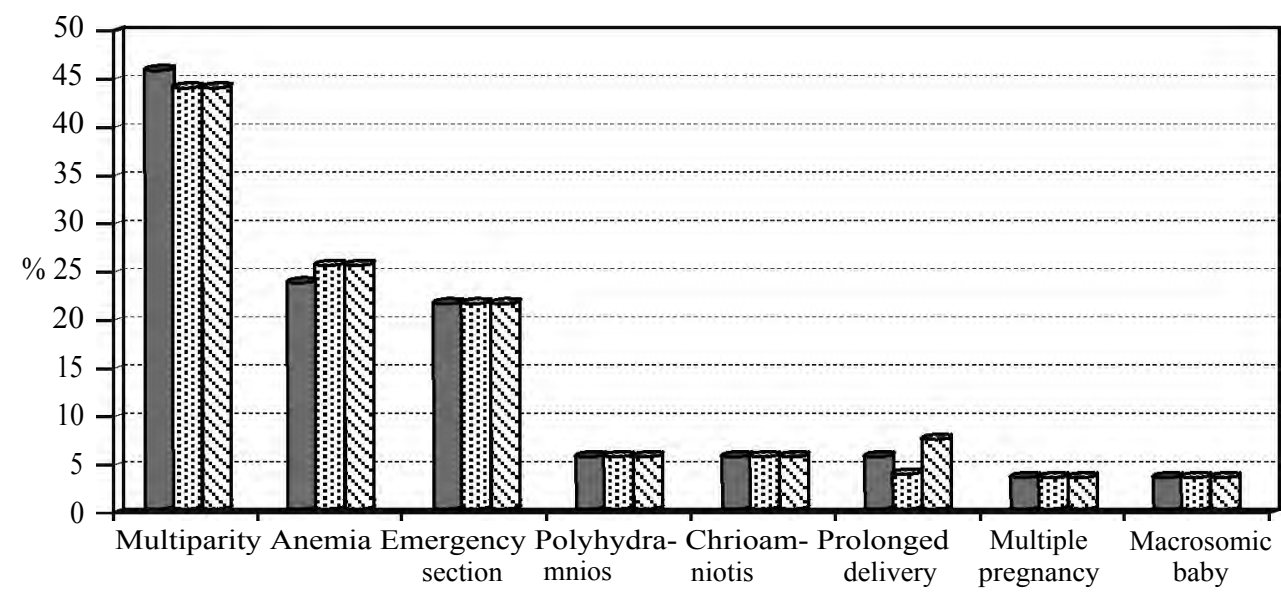

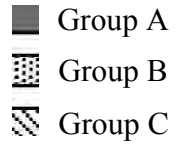

Fig. (1): Bar chart risks for atony among both groups. 


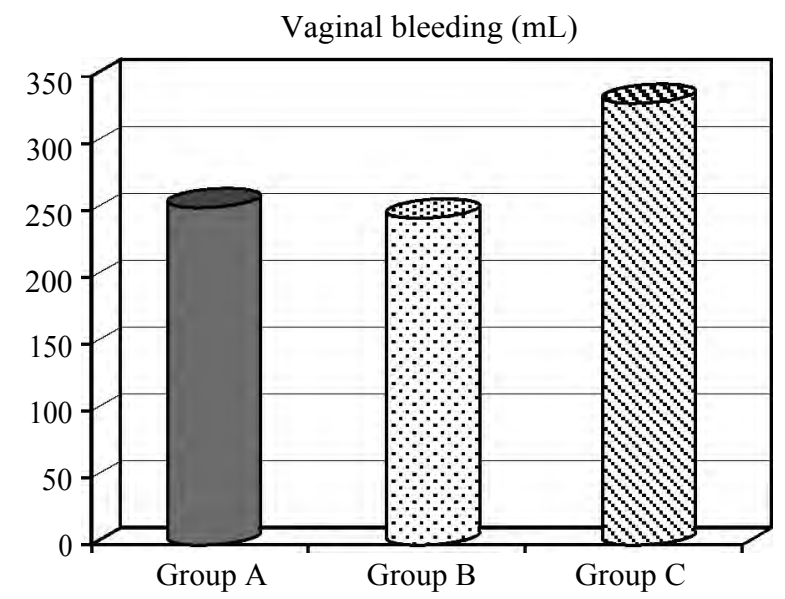

Fig. (2): 1 st 6 hours Postoperative vaginal bleeding among the studied groups.

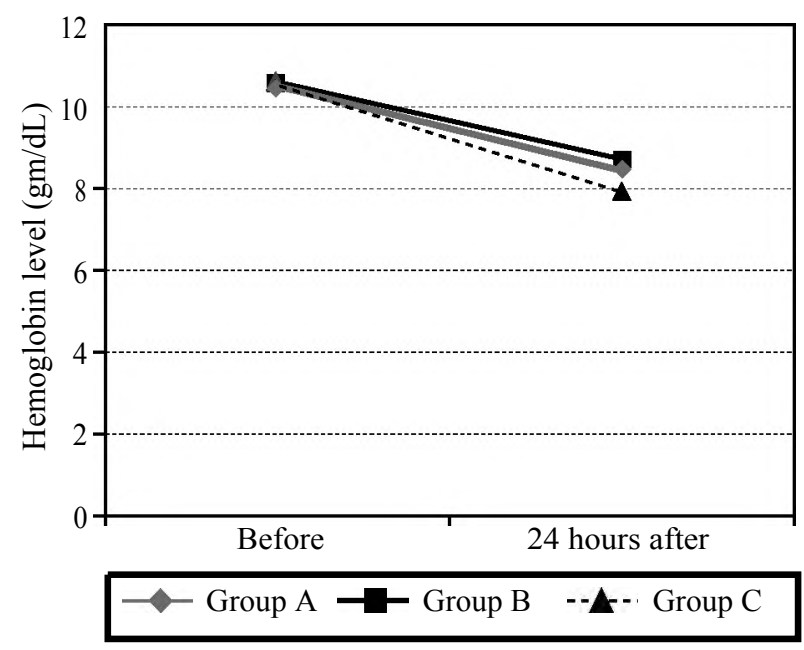

Fig. (4): Hemoglobin level among the studied groups.

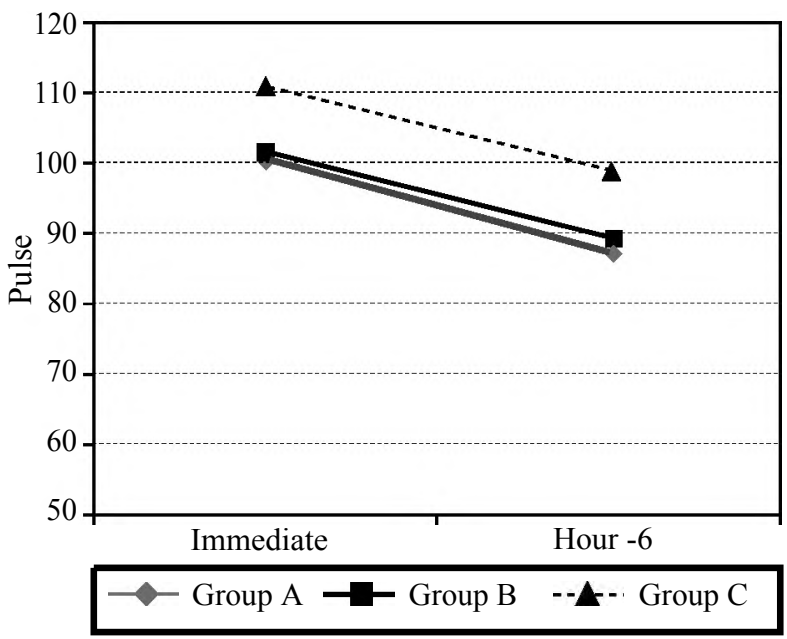

Fig. (6): Immediate and 6-hours Postoperative pulse among the studied groups.

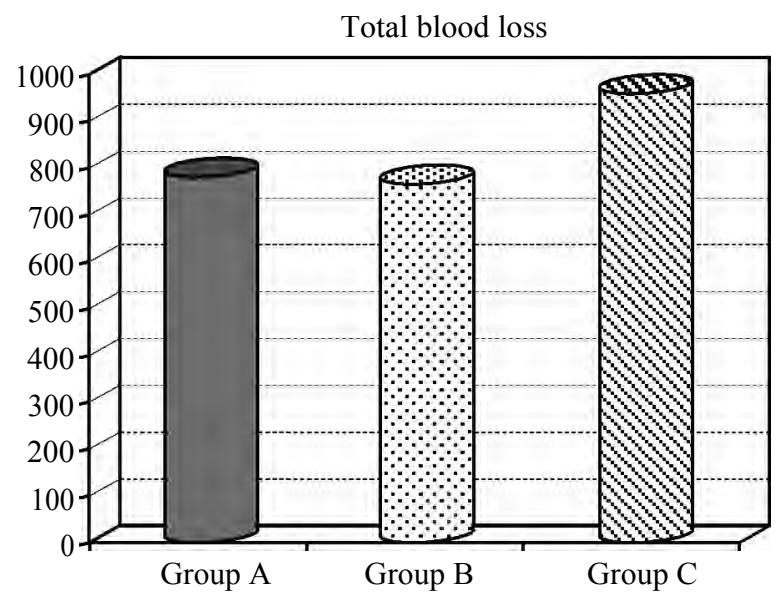

Fig. (3): Total blood loss among the studied groups.

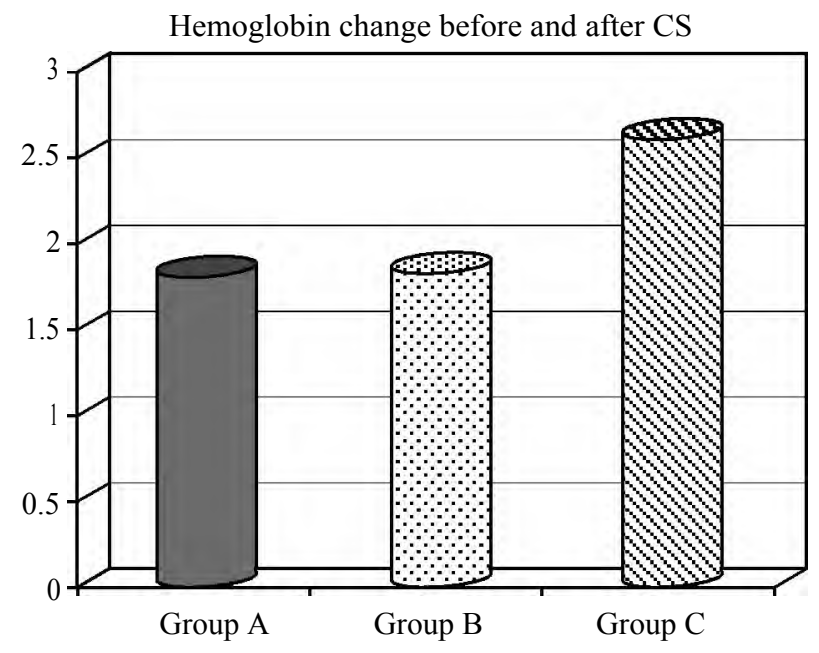

Fig. (5): Hemoglobin change before and after CS.

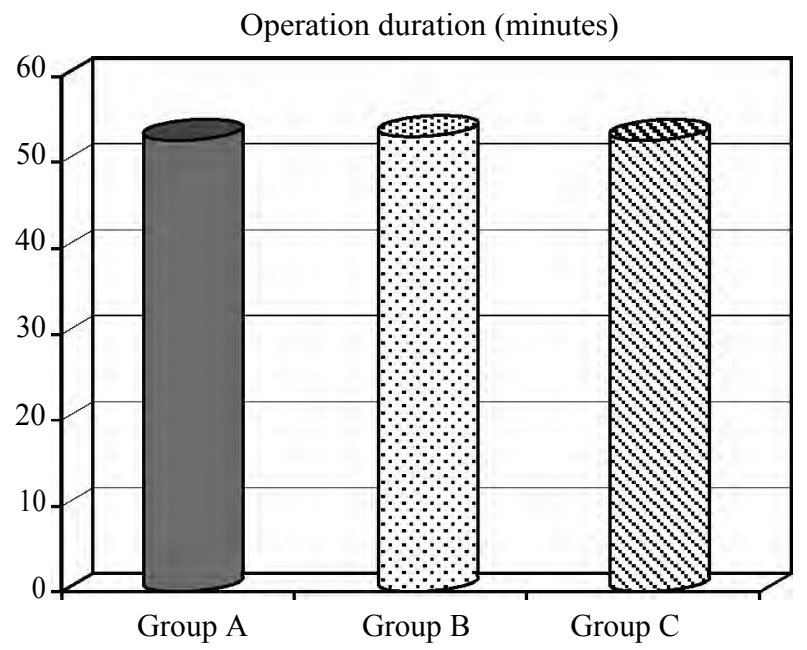

Fig. (7): Operation duration among the studied groups. 


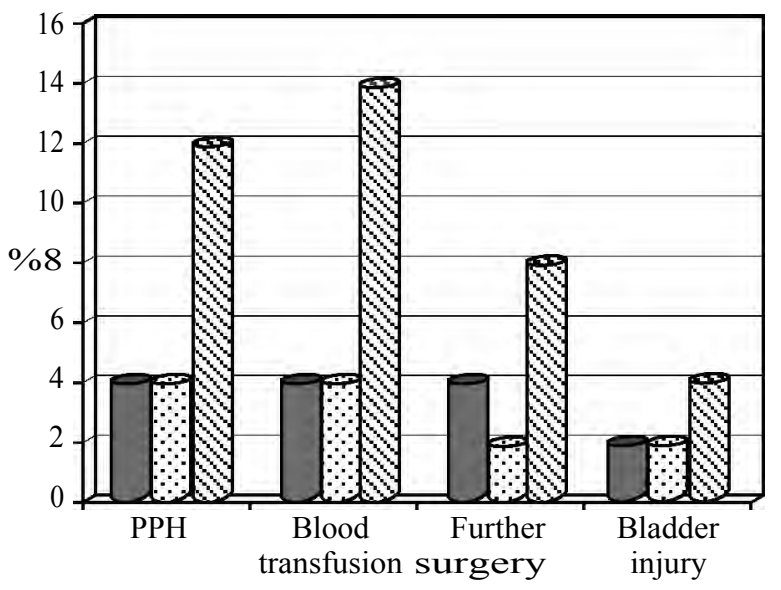

Group A

Fig. (8): Postoperative complications among the studied groups.

\section{Discussion}

Obstetric hemorrhage remains one of the major causes of maternal death in both developed and developing countries. Because of its importance as a leading cause of maternal mortality and morbidity, and because of evidence of substandard care in the majority of fatal cases, obstetric hemorrhage must be considered as a priority topic for national research development [12] .

Various uterine compression sutures and the balloon tamponade have been introduced for the management of PPH in the last two decades which became very popular and widely accepted all over the world. The B Lynch uterine compression suture is the first and most commonly used uterine compression sutures and has major advantages over other methods such as lack of need for special setting as well as quick and easy application (because the same suture used for closure of the uterine incision can be used). These advantages are very important in maternity hospitals with low resource settings. The success rates and possible complications of the B Lynch uterine compression suture have been evaluated in many studies, case serious, and case repots however further studies are needed to address possible risks and pitfalls [13].

In a study a review of the data from various study groups indicates that utrine artery occlusion is a safe and effective intervention in the mangment of severe PPH, and it does not appear to compromise a womans subsequent fertility and obstetric outcomes. Results suggest that women who undergo this procedure can expect to have a return of normal menses, with no long term adverse effect on fertility [14] .

Other studies mainly studied use of utrine compression suture as a treatment of PPH not as a prophylaxis, only the study Vijayasree et al., [15] studied its use as prophylaxis.

Other studies mainly studied use of bilateral utrine artery occlusion as a treatment of PPH not as prophylaxis; only the study Liu et al., [16] studied its use as prophylaxis.

In our study there are 3 groups, 2 study groups every one is 50 women, and control group is 50 women. While the two studies mentioned above the study Vijayasree et al., [15] there was only one group while the study Liu et al., [16] there was two groups study and control groups.

In the study Vijayasree et al., [15] the study group, 40 women, whereas no control group.

While in the study Liu et al., [16] the studygroup, 26 women, whereas the control group, 22 women.

In our study there was no significant difference as regard patient characteristics (age, weight, BMI, parity and gestional age) between the two study and control groups.

In the study Vijayasree et al., [15] patient characteristics not mentioned Vijayasree et al., [15].

In the study Liu et al., [16] the patients characteristics in the two groups were similar, with no statistical difference between the two groups [16]

Our results show that no statistically difference between uterine compression suture (B-Lynch) and bilateral uterine artery ligation in decreasing blood loss after cesarean section. And both reducing blood loss. The study groups total blood loss after delivery by 6 hours postoperative $(251.02 \pm 21.83 \mathrm{ml})$ and $(246.00 \pm 21.39 \mathrm{ml})$ was significantly less than control group $(332.62 \pm 18.87 \mathrm{ml})(p<0.001)$. These results agree with the results of the mentioned studies.

The results support other studies except they only measured the intraoperative blood loss.

The previous study of Vijayasree et al., [15] show that B-Lynch suture decrease blood loss postpartum in emergency CS. 
The previous study of Liu et al., [16] bilateral uterine artery ligation significantly reduced the quantity of blood loss during cesarean section in patient with fibroid uterus.

In our study there was significant statistical difference in the vital data immediate and 6 hours postoperative between the study groups and control group.but no significant statistical difference between the study groups. While in the study of Vijayasree et al., [15] and study of Liu et al., [16] vital data assessment was not mentioned.

In our study postoperative hemoglobin was significantly higher in study groups than control group $(p<0.001)$. Reduction in Hemoglobin was significantly less in study groups than in control group $(p<0.001)$. But there is no significant difference between the study groups.

Also postoperative hematocrite was significantly higher in study groups than control group ( $p<$ $0.001)$. Reduction in hematocrit was significantly less in study groups than control group $(p<0.001)$. But there is no statically difference between the study groups.

In the study of Vijayasree et al., [15] the average hemoglobin level was $9.8 \mathrm{gms} / \mathrm{dl}$. Pre-operative and post-operative hemoglobin levels differed by 0.4 to $1.8 \mathrm{gms} / \mathrm{dl}$. Hematocrit level not mentioned.

In the study of Liu et al. [16], Pre-operative baseline hemoglobin values measured showed no significant differences between the two groups. In the group I patients, Intraoperative blood loss was lower and the first day postoperative hemoglobin level was higher, but without significant difference between the patients of both groups.

In our study there was no significant difference between all groups in the operative time. Also in the study of Liu et al., [16], the operative time was a little longer for group I than group II patients. However, this was statistically insignificant. In the study of Vijayasree et al., [15] mentioned that BLynch suture took additional extra four minutes after a normal CS to apply it.

In our study the included patients were those who are at risk of uterine atony as multipara, twin pregnancy, going for emergency CS, Macrosomic baby, Polyhydramonis, patients with anemia or chorioamnionitis.

However, the study of Vijayasree et al., [15], risk factors involved Eclampcia, Multiple gestation,
Polyhydramonis, prolonged second stage of labor, and chorioamnionitis.

However, the study of Liu et al., [16] included patients with fibroid uterus undergoing cesarean section for obstetric reasons.

Draw backs of our study: No other studies compare the efficacy of two maneuvers but there was studies study every maneuver alone. Short term follow up only one weak postpartum and no long term follow up for continuation of menstruation and future fertility of patients.

But other studies observed for continuation of menstruation and future fertility after bilateral occlusion of uterine arteries or B-Lynch suture.

As regard long term follow-up for menstrual pattern and future fertility in other studies:

Corr [17] showed that $100 \%$ of patients regained regular menstruation after UAE.

Fiori et al., [18] showed that $91 \%$ of women reported regular menses following the UAE procedure. Only 3 patients $(9 \%)$ reported menstrual disorders: 1 had hypomenorrhoea related to a partial corporeal uterine synechiae; 1 reported metrorrhagia related to diffuse uterine adenomyosis; and 1 , aged 46.5 years, reported irregular menstrual bleeding for more than a year.

Gaia et al., [19] performed one of the largest cohort studies, 107 women were followed up after UAE, 99 women regained menses, and only 6 women had amenorrhea due to synechiae proved by hysteroscopy.

Sentilhes et al., [20] studied 68 women who underwent UAE only or in combination with uterussparing surgery (B-Lynch or internal iliac artery ligation), 8 women complained of amenorrhea or decreased menstrual flow following UAE, and 19 women had term deliveries, 6 of them had recurrent PPH.

\section{Conclusion:}

There is no difference between uterine compression suture (B-Lynch) suture and bilateral uterine artery ligation in prevention of postpartum hemorrhage; while both maneuver are effective as a prophylaxis against postpartum hemorrhage as shown by the results of this study. There can significantly reduce blood loss after cesarean section.

Our data demonstrated, that uterine compression suture (B-Lynch) and bilateral uterine artery ligation 
can be used safely to reduce bleeding after CS as there use was not associated with any significant maternal and neonatal side effects.

\section{References}

1- CHAI V.Y. and TO W.W.: Uterine compression sutures for management of severe postpartum haemorrhage: fiveyear audit. Hong. Kong. Med. J., 20 (2): 113-120, 2014.

2- American College of Obstetricians and Gynecologists: ACOG Practice Bulletin: Clinical Management Guidelines for Obstetrician-Gynecologists Number 76, October 2006 Postpartum hemorrhage. Obstet. Gynecol., 108 (4): 103947, 2006.

3- COOMBS C.A., MURPHY E.L. and LAROS R.K.: Factors associated with postpartum hemorrhage with vaginal birth. Obstet. Gynecol., 77: 69-76, 2011.

4- KOH E., DEVENDRA K. and TAN L.K.: B-Lynch suture for the treatment of uterine atony. Singapore Med. J., 50 (7): 693-69, 2009.

5- AVERY D.M.: Review of Medical and Surgical Management of Postpartum Hemorrhage. American Journal of Clinical Medicine. Volume Eight. Number one, 2011.

6- B-LYNCH C., COKER A., LAWAL A.H., ABDU J. and COWEN M.J.: The B-Lynch surgical technique for control of massive postpartum hemorrhage: An alternative to hysterectomy? Five cases reported. Br. J. Obstet. Gynecol., 104: 372-5, 2007

7- MAJUMDAR A., MALLICK K., VASAVA B., DESAI K. and DALAL M.: A descriptive study on Hayman suture technique to control postpartum hemorrhage. Sri Lanka Journal of Obstetrics and Gynaecology, 34 (3), 2012.

8- HACKETHAL A., BRUEGGMANN D., OEHMKE F., TINNEBERG H.R., ZYGMUNT M.T. and MUENSTEDT K.: Uterine compression U-sutures in primary postpartum hemorrhage after Cesarean section: Fertility preservation with a simple and effective technique. Human Reproduction, 23 (1): 74-79, 2007.

9- HAYMAN R.G., ARULKUMARAN S. and STEER P.J. Uterine compression sutures: Surgical management of postpartum hemorrhage. Obstet. Gynecol., 99: 502-6, 2002.

10- ALLAM M.S. and B-LYNCH C.: The B-Lynch and other uterine compression suture techniques. Int. J. Gynaecol. Obstet., 89: 236-41, 2005.
11- ATIN H. and SHYAMAPADA P.: Uterine and ovarian arteries ligation: A safe technique to control PPH during cesarean section. J. Obstet. Gynecol. India, 58 (4): 31921, 2008.

12- PENNEY G. and BRACE V.: Near miss audit in obstetrics. Curr. Opin. Obstet. Gynecol., 19: 145-50, 2007.

13- KAYA B., TUTEN A., DAGLAR K., ONKUN M., SUCU S., DOGAN A. and GURALP O.: B-Lynch uterine compression sutures in the conservative surgical management of uterine atony. Archives of Gynecology and Obstetrics, 291 (5): 1005-1014, 2015.

14- DOUMOUCHTSIS S.K., NIKOLOPOULOS K., TALAULIKAR V.S., KRISHNA A. and ARULKUMARAN S. Menstrual and fertility outcomes following the surgical management of postpartum haemorrhage: A systematic review. BJOG, 121: 382-388, 2014.

15- VIJAYASREE M.: Efficacy of Prophylactic B-Lynch Suture during Lower Segment Caesarian Section in High Risk Patients for Atonic Postpartum Haemorrhage. Kathmandu University Medical Journal (KUMJ), 14 (53): 9$12,2016$.

16- LIU W.M., WANG P.H., TANG W.L. and TZENG C.R.: Uterine artery ligation for treatment of pregnant women with uterine leiomyomas who are undergoing cesarean section. Fertility and Sterility, 86 (2): 423-428, 2006.

17- CORR P.: Arterial embolization for haemorrhage in the obstetric patient. Best. Pract. Res. Clin. Obstet. Gynaecol., 15: 557-61, 2003.

18- FIORI O., DEUX J.F., KAMBALE J.C., UZAN S., BOU GDHENE F. and BERKANE N.: Impact of pelvic arterial embolization for intractable postpartum hemorrhage on fertility. Am. J. Obstet. Gynecol., 200 (384): e1-4, 2009.

19- GAIA G., CHABROT P., CASSAGNES L., CALCAGNO A., GALLOT D., BOTCHORISHVILI R. and BOYER L.: Menses recovery and fertility after artery embolization for PPH: A single-center retrospective observational study. European Radiology, 19 (2): 481-487.

20- SENTILHES L., GROMEZ A., CLAVIER E., RESCH B., VERSPYCK E. and MARPEAU L.: Fertility and pregnancy following pelvic arterial embolisation forpostpartum haemorrhage. BJOG, 117: 84-93, 2010. 


\section{دراسة مستقبلية مقارن ما بين الغرز الضاغطة للرحم (فرزة (B-Lynch)

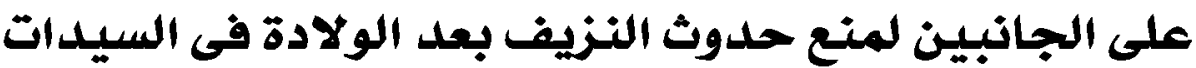

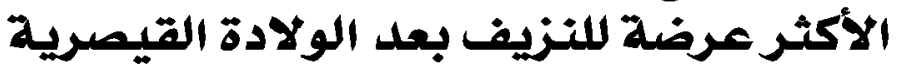

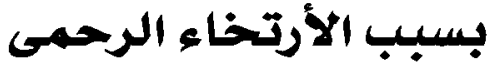

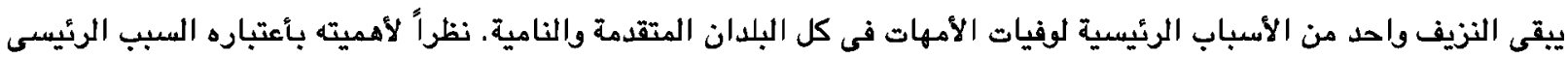

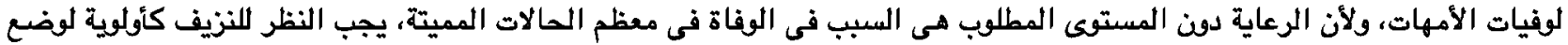

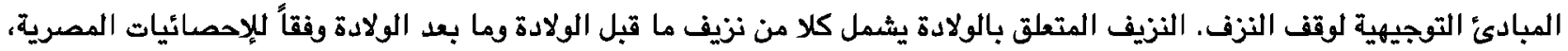

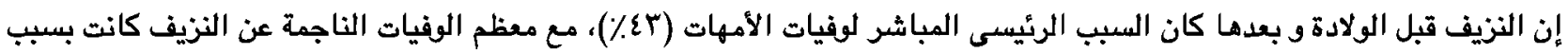
نزيف ما بعد الولادة.

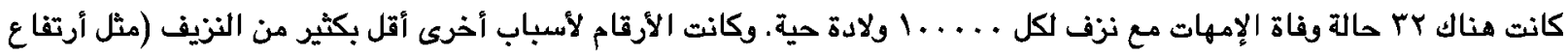

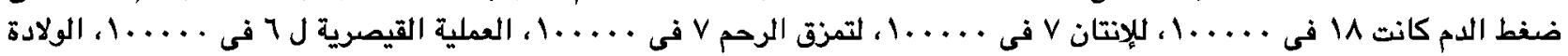

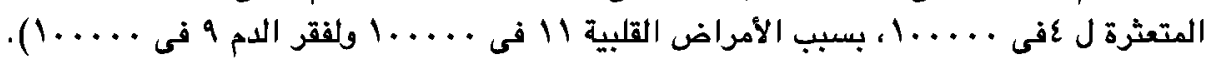

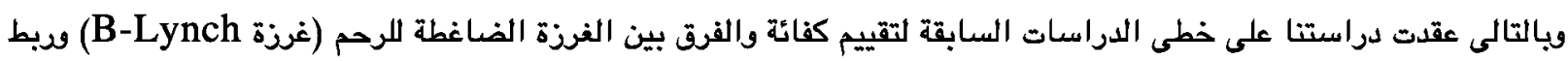

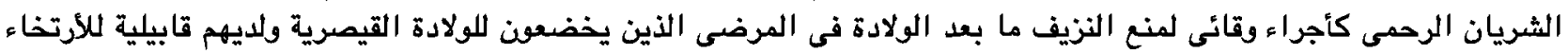

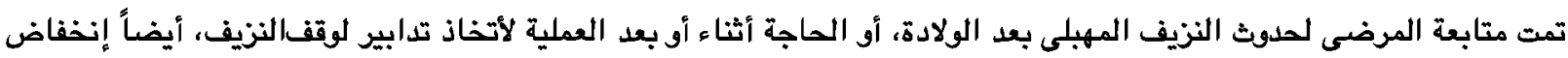

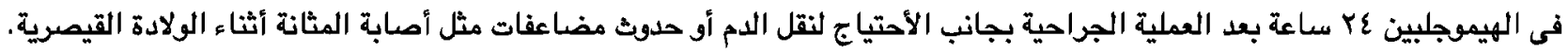
- وفى الدراسة الحالية لا يوجد فرق كبير بين مجموعتى الدراسة ومجموعة التحكم فيما يتعلق بالسن ومؤشر كتلة الجسم.

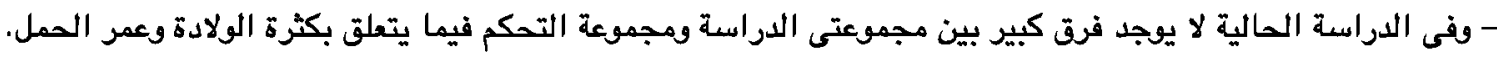

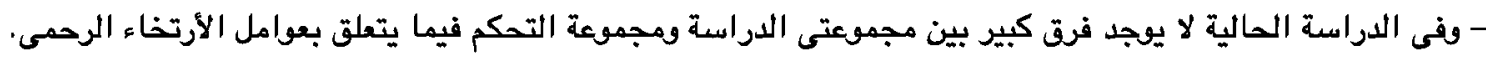

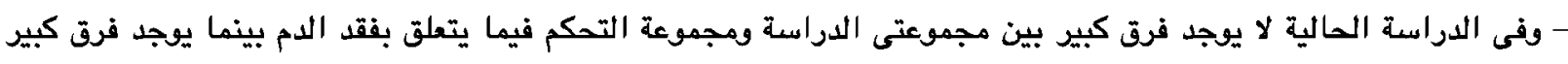
بين مجموعتى الدراسة ومجموعة التحكم.

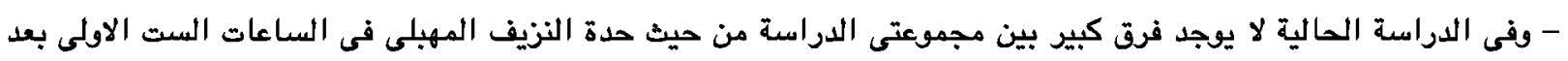

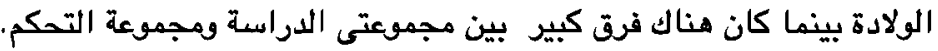

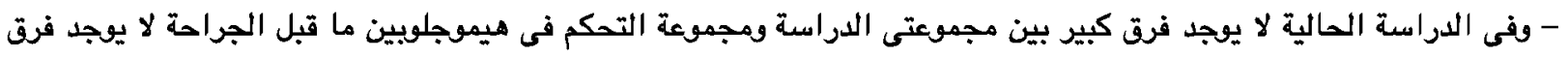

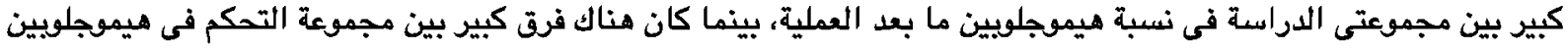
ما بعد العملية، وكان أنخفاض الهيموجلويين أقل بكثير في مجموعتى الدراسة من مجموعية التحكم. 